\title{
PENGARUH GAYA KEPEMIMPINAN PARTISIPATIF, DISIPLIN KERJA DAN LINGKUNGAN KERJA TERHADAP KINERJA GURU DI SMA NEGERI 1 NA IX-X KABUPATEN LABUHANBATU UTARA
}

\author{
${ }^{1}$ Nurasiah Nasution, ${ }^{2}$ Poltak, ${ }^{3}$ Eddi Sonti, ${ }^{4}$ Ramlan Taufik, ${ }^{5}$ Mhd.Affan Daulay \\ $1,2,3,4,5$ Universitas Islam Sumatera Utara \\ Inurasiah.nst@gmail.com, 22poltak.mm@gmail.com, ${ }^{3}$ eddi.sonti@gmail.com, ${ }^{4}$ ramlan.taufik@gmail.com, \\ ${ }^{5}$ mhd.affandaulay@gmail.com
}

\begin{abstract}
The formulation of the problem in this study is whether there is an influence of participatory leadership style on the performance of teachers and employees. Is there an effect of work discipline on the performance of teachers and employees. Is there an influence of the work environment on the performance of teachers and employees. Is there an influence of participatory leadership style, work discipline and work environment on the performance of teachers and employees of SMA Negeri 1 NA IX-X in North Labuhanbatu Regency. The purpose of this study was to determine and analyze the influence of participatory leadership styles on teacher and employee performance. Effect of work discipline on teacher and employee performance. The influence of the work environment on the performance of teachers and employees. The influence of participatory leadership style, work discipline and work environment on the performance of teachers and employees of SMA Negeri I NA IX-X in North Labuhanbatu Regency. The sample in this study amounted to 52 people. The data analysis technique used in this research is descriptive analysis and multiple linear regression analysis. The results of this study explain that the variables of work discipline and work environment have a positive and significant effect on teacher and employee performance. The participatory leadership style variable does not have a positive and significant effect on the performance of teachers and employees. The variables of participatory leadership style, work discipline and work environment have a positive and significant effect on the performance of teachers and employees of SMA Negeri 1 NA IX-X in North Labuhanbatu Regency.
\end{abstract}

Keywords:Participatory leadership style, work discipline, work environment, performance

\begin{abstract}
ABSTRAK : Rumusan masalah dalam penelitian ini adalah apakah ada pengaruh gaya kepemimpinan partisipatif terhadap kinerja guru dan pegawai. Apakah ada pengaruh disiplin kerja terhadap kinerja guru dan pegawai. Apakah ada pengaruh lingkungan kerja terhadap kinerja guru dan pegawai. Apakah ada pengaruh gaya kepemimpinan partisipatif, disiplin kerja dan lingkungan kerja terhadap kinerja guru dan pegawai SMA Negeri 1 NA IX-X Kabupaten Labuhanbatu Utara. Tujuan penelitian ini adalah untuk mengetahui dan menganalisis pengaruh gaya kepemimpinan partisipatif terhadap kinerja guru dan pegawai. Pengaruh disiplin kerja terhadap kinerja guru dan pegawai. Pengaruh lingkungan kerja terhadap kinerja guru dan pegawai. Pengaruh gaya kepemimpinan partisipatif, disiplin kerja dan lingkungan kerja terhadap kinerja guru dan pegawai SMA Negeri 1 NA IX-X Kabupaten Labuhanbatu Utara. Sampel dalam penelitian ini berjumlah 52 orang. Teknik analisis data yang digunakan dalam penelitian ini adalah analisis deskriptif dan analisis regresi linier berganda. Hasil penelitian ini menjelaskan bahwa variabel disiplin kerja dan lingkungan kerja berpengaruh positif dan signifikan terhadap kinerja guru dan pegawai. Variabel gaya kepemimpinan partisipatif tidak berpengaruh positif dan signifikan terhadap kinerja guru dan pegawai. Variabel gaya kepemimpinan partisipatif, disiplin kerja dan lingkungan kerja berpengaruh positif dan signifikan terhadap kinerja guru dan pegawai SMA Negeri 1 NA IX-X Kabupaten Labuhanbatu Utara.
\end{abstract}

Kata Kunci : Gaya kepemimpinan partisipatif, Disiplin kerja, Lingkungan kerja, Kinerja 


\section{Pendahuluan}

Dunia pendidikan merupakan institusi yang mempunyai peranan penting dalam meningkatkan kualitas sumber daya manusia. Peran ini terkait dengan upaya menjadikan generasi penerus bangsa yang mempunyai kualitas sumber daya manusia yang dapat diandalkan. Dalam meningkatkan kualitas sumber daya manusia dari sektor pendidikan, guru memiliki peran yang besar dalam proses pendidikan, untuk itu manajemen harus mampu menciptakan situasi yang dapat mendorong timbulnya rasa memiliki, loyalitas, kesetiakawanan, rasa aman, rasa diterima dan dihargai, serta perasaan berhasil dalam diri guru yang pada gilirannya dapat menimbulkan rasa keterikatan dan mengembangkan semangat kerja yang optimal. Pada hakikatnya penyelenggaraan dan keberhasilan proses pendidikan pada semua jenis dan jenjang pendidikan ditentukan oleh kinerja yang ditampilkan dari seorang guru dan kemudian ditunjang oleh unsur-unsur lainnya.

Guru sebagai yang menentukan terselenggaranya pendidikan yang bermutu, hanya dengan guru yang kompeten, profesional dan memiliki kepribadian yang baiklah maka kegiatan belajar mengajar dapat berlangsung dengan lancar dan berkualitas. Disinilah dituntut motivasi kerja guru untuk mengembangkan sumber daya manusia yang berkualitas. Pelaksanaan motivasi kerja guru dalam melakukan tugas, akan tergantung pada kemampuan dan kesungguhan kinerjanya.

Kinerja guru sangat penting untuk diperhatikan dan dievaluasi karena guru mengemban tugas profesional artinya tugastugas hanya dapat dikerjakan dengan kompetensi khusus yang diperoleh melalui program pendidikan. Menurut Danim (2002:83), guru memiliki tanggung jawab yang secara garis besar dapat dikelompokkan yaitu guru sebagai pengajar, guru sebagai pembimbing dan guru sebagai administrator kelas.

Untuk mendapatkan proses dan hasil belajar siswa yang berkualitas tentu memerlukan kinerja guru yang maksimal. Agar guru dapat meningkatkan kinerjanya, guru harus mendapat dukungan dari kepala sekolah sebagai top manajemen dalam organisasi. Berdasarkan peneltian yang pernah di lakukan gaya kepemimpinan pernah dilakukan penelitian oleh Fajrie di tahun 2015 di Sekolah Dasar Negeri Kota Depok, dimana hasil penelitian itu menyebutkan bahwa variabel gaya kepemimpinan partisipatif berpengaruh signifikan terhadap kinerja guru di sekolah tersebut. Fenomena yang terjadi di lingkungan SMA Negeri 1 NA IX-X Kabupaten Labuhanbatu Utara, peneliti melihat relatif lamanya waktu dalam menentukan kebijakankebijakan yang akan diputuskan bersama serta seringnya terjadi konflik horisontal saat musyawarah berlangsung.

Berikutnya variabel yang menjadi pengamatan awal oleh peneliti di lingkungan SMA Negeri 1 NA IX-X Kabupaten Labuhanbatu Utara adalah disiplin kerja guru. Guru sebagai teladan dan panutan oleh para siswa harus memberi contoh yang baik, dalam hal berdisiplin baik. Jika disiplin guru kurang baik (kurang berdisiplin), para siswa pun akan kurang disiplin. Guru jangan mengharapkan kedisiplinan siswanya baik jika dia sendiri kurang disiplin. Menurut Siswanto (2002:291), disiplin kerja adalah sebagai suatu sikap menghormati, menghargai, patuh dan taat terhadap peraturan-peraturan yang berlaku, baik yang tertulis maupun tidak tertulis serta sanggup menjalankan dan tidak mengelak untuk menerima sangsi-sangsi apabila ia melanggar tugas dan wewenang yang diberikan.

Fenomena yang terjadi di lingkungan SMA Negeri 1 NA IX-X Kabupaten Labuhanbatu Utara, peneliti melihat masih adanya ditemukan guru dan pegawai yang indisipliner, misalnya datang tidak tepat waktu, pulang masih dalam jam bekerja walaupun tidak ada jam mengajar, dan ditemukan juga guru dan pegawai yang tidak menggunakan seragam yang sesuai dengan ketetapan oleh pihak sekolah.

Pada penelitian sebelumnya mengenai variabel disiplin ini pernah dilakukan oleh Adrijanti di tahun 2014 di Sekolah Dasar Negeri Sumari Duduk Sampeyan Gresik, dimana dalam penelitiannya tersebut menghasilkan bahwa variabel disiplin kerja berpengaruh cukup besar terhadap kinerja guru di SDN Sumari Duduk Sampeyan. Hal ini menjadi tolok ukur peneliti mencoba untuk melakukan penelitian dengan variabel yang sama di SMA Negeri 1 NA IX-X Kabupaten Labuhanbatu Utara.

Variabel yang terakhir menjadi pengamatan awal oleh peneliti di SMA Negeri 1 NA IX-X Kabupaten Labuhanbatu Utara ini adalah lingkungan kerja guru. Menurut Lewa dkk (2005:75), lingkungan kerja yang baik yaitu apabila pegawai dapat melaksanakan 
kegiatan secara optimal, sehat, aman, dan nyaman. Lingkungan kerja yang tidak memadai akan dapat menurunkan kinerja. Suatu kondisi lingkungan kerja dikatakan baik atau sesuai apabila manusia dapat melaksanakan kegiatan secara optimal, sehat, aman dan nyaman. Fenomena yang terjadi di lingkungan sekolah SMA Negeri 1 NA IX-X Kabupaten Labuhanbatu Utara adalah masih minimnya penerangan yang ada di ruang guru sehingga menyebabkan guru bekerja hanya mengharapkan cahaya masuk dari jendela dan pintu masuk ruang guru, sirkulasi udara yang kurang baik mengganggu aktivitas guru dalam bekerja dan banyaknya buku-buku serta berkas di ruang kerja yang tidak tertata dengan baik menyebabkan kenyamanan guru terganggu.

\subsection{Batasan Masalah}

Penelitian ini hanya dibatasi pada gaya kepemimpinan partisipatif, disiplin kerja dan lingkungan kerja terhadap kinerja guru di SMA Negeri 1 NA IX-X Kabupaten Labuhanbatu Utara.

\subsection{Hioptesis}

Berdasarkan rumusan masalah tujuan penelitian, kajian teori, dan kerangka konseptual yang telah dikemukakan diatas, maka rumusan hipotesis penelitian ini dapat dirumuskan sebagai berikut:

1) Gaya kepemimpinan partisipatif berpengaruh signifikan terhadap kinerja guru di SMA Negeri 1 NA IX-X Kabupaten Labuhanbatu Utara.

2) Disiplin kerja berpengaruh signifikan terhadap kinerja guru di SMA Negeri 1 NA IX-X Kabupaten Labuhanbatu Utara.

3) Lingkungan kerja berpengaruh signifikan terhadap kinerja guru di SMA Negeri 1 NA IX-X Kabupaten Labuhanbatu Utara.

4) Gaya kepemimpinan partisipatif, disiplin kerja dan lingkungan kerja secara bersamasama berpengaruh signifikan terhadap kinerja guru di SMA Negeri 1 NA IX-X Kabupaten Labuhanbatu Utara.

\subsection{Tujuan Penelitian}

Berdasarkan rumusan masalah penelitian sebagaimana diuraikan di atas, maka tujuan yang akan dicapai dalam penelitian ini yaitu untuk menganalisis:

1) Pengaruh gaya kepemimpinan partisipatif terhadap kinerja guru di SMA Negeri 1 NA IX-X Kabupaten Labuhanbatu Utara.
2) Pengaruh disiplin kerja terhadap kinerja guru di SMA Negeri 1 NA IX-X Kabupaten Labuhanbatu Utara.

3) Pengaruh lingkungan kerja terhadap kinerja guru di SMA Negeri 1 NA IX-X Kabupaten Labuhanbatu Utara.

4) Pengaruh gaya kepemimpinan partisipatif, disiplin kerja dan lingkungan kerja terhadap kinerja guru di SMA Negeri 1 NA IX-X Kabupaten Labuhanbatu Utara.

\section{Metode Penelitian}

\subsection{Populasi}

Populasi dalam penelitian merupakan merupakan wilayah yang ingin di teliti oleh peneliti. Seperti menurut Sugiyono (2011:80), definisi populasi adalah wilayah generalisasi yang terdiri atas obyek / subyek yang mempunyai kualitas dan karakteristik tertentu yang ditetapkan oleh peneliti untuk dipelajari dan kemudian ditarik kesimpulannya.

Pendapat di atas menjadi salah satu acuan bagi peneliti untuk menentukan populasi penelitiannya. Populasi yang akan digunakan sebagai penelitian adalah seluruh pegawai dan guru yang ada di SMA Negeri 1 NA IX-X Kabupaten Labuhanbatu Utara yang berjumlah 53 orang.

\subsection{Sampel}

Sampel merupakan bagian dari populasi yang ingin di teliti oleh peneliti. Menurut Sugiyono (2011:81) sampel adalah bagian dari jumlah dan karakteristik yang dimiliki oleh populasi tersebut. Sehingga sampel merupakan bagian dari populasi yang ada, sehingga untuk pengambilan sampel harus menggunakan cara tertentu yang didasarkan oleh pertimbanganpertimbangan yang ada. Dalam teknik pengambilan sampel ini penulis menggunakan teknik sampling purposive. Sugiyono (2011:84) menjelaskan bahwa: "Sampling Purposive adalah teknik penentuan sampel dengan pertimbangan tertentu." Dari pengertian diatas agar memudahkan penelitian, peneliti menetapkan sifat-sifat dan katakteristik yang digunakan dalam penelitian ini.

Menurut Arikunto (2006:112) mengatakan bahwa "apabila subjeknya kurang dari seratus, lebih baik diambil semua sehingga penelitianya merupakan populasi. Tetapi jika jumlah subjek besar dapat diambil antara $10-15 \%$ atau $15-25 \%$ atau lebih." Pendapat tersebut sesuai menurut Roscoe dalam Sugiyono (2011:90) ukuran 
sampel yang layak dalam penelitian adalah antara 30 sampai dengan 500 .

Karena jumlah subjeknya kurang dari seratus maka sampel dalam penelitian ini diambil keseluruhannya yakni sebanyak 52 orang guru dan pegawai (1 orang pimpinan tertinggi tidak dilakukan penelitian).

\subsection{Uji Normalitas}

Pengujian normalitas data bertujuan untuk melihat normal tidaknya sebaran data yang akan dianalisis. Model regresi yang baik adalah distribusi normal atau mendekati normal. Untuk melihat normalitas data ini digunakan pendekatan grafik yaitu Normality Probability Plot.

Deteksi normalitas dengan melihat penyebaran data (titik) pada sumbu diagonal dari grafik. Menurut Santoso (2004:214), dasar pengambilan keputusan adalah:

a. Jika data menyebar disekitar garis diagonal dan mengikuti arah garis diagonal, maka model regresi memenuhi asumsi normalitas.

b. Jika data menyebar jauh dari garis diagonal dan atau tidak mengikuti arah garis diagonal, maka model regresi tidak memenuhi asumsi normalitas.

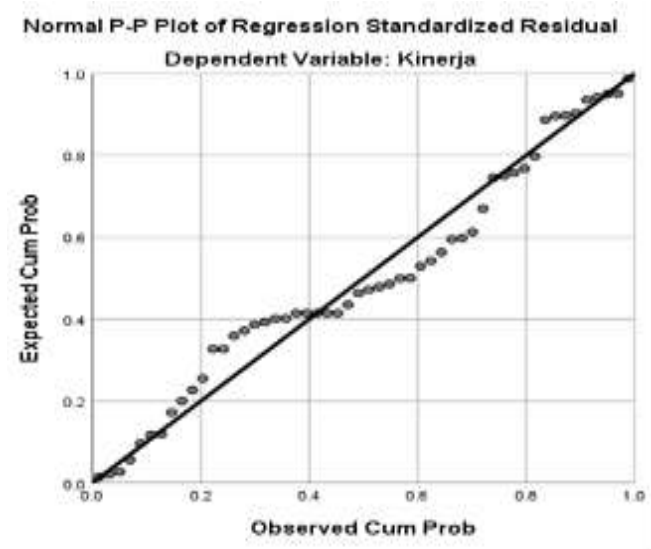

Gambar 1. Normalitas Data

Pada output SPSS seperti gambar diatas diketahui bagian normal P-P Plot of Regresion Standardized Residual, dapat dijelaskan bahwa data-data (titik-titik) cenderung lurus mengikuti garis diagonal sehingga data dalam penelitian ini cenderung berdistribusi normal.

\subsection{Uji Multikolinearitas}

Pengujian multikolinearitas dilakukan untuk melihat apakah pada model regresi ditemukan adanya korelasi antara variabel bebas. Jika terjadi korelasi, maka dinamakan terdapat problem multikolinearitas. Cara mendeteksinya adalah dengan melihat nilai Variance Inflation Factor (VIF). Menurut Santoso (2004:203), pada umumnya jika VIF lebih besar dari 5 , maka variabel bebas tersebut mempunyai persoalan multikolinearitas dengan variabel bebas lainnya.

Tabel 1. Hasil Uji Multikolinearitas

Coefficients $^{\mathrm{a}}$

\begin{tabular}{|c|c|c|c|c|c|c|c|c|}
\hline \multirow{3}{*}{\multicolumn{2}{|c|}{ Model }} & \multirow{2}{*}{\multicolumn{2}{|c|}{$\begin{array}{l}\text { Unstandardized } \\
\text { Coefficients }\end{array}$}} & \multirow{3}{*}{$\begin{array}{l}\text { Standardized } \\
\text { Coefficients } \\
\text { Beta }\end{array}$} & \multirow{3}{*}{$\mathrm{t}$} & \multirow{3}{*}{ Sig. } & \multirow{2}{*}{\multicolumn{2}{|c|}{$\begin{array}{l}\text { Collinearity } \\
\text { Statistics }\end{array}$}} \\
\hline & & & & & & & & \\
\hline & & B & $\begin{array}{l}\text { Std. } \\
\text { Error }\end{array}$ & & & & Tolerance & VIF \\
\hline \multirow{4}{*}{1} & (Constant) & 3.381 & 2.533 & & 1.335 & .188 & & \\
\hline & Gaya.Kep.Partisipatif & -.027 & .067 & -.032 & -.399 & .692 & .784 & 1.275 \\
\hline & Disiplin.Kerja & .189 & .088 & .178 & 2.149 & .037 & .712 & 1.404 \\
\hline & Lingkungan.Kerja & .728 & .080 & .783 & 9.110 & .000 & .664 & 1.506 \\
\hline
\end{tabular}

a. Dependent Variable: Kinerja

Berdasarkan nilai hasil perhitungan dengan SPSS diperoleh data nilai VIF sebesar 1.275, 1.404 dan 1.506 dengan nilai toleransi 0.784 , 0.712 , dan 0.664 , hal ini menunjukkan adanya korelasi yang cukup kuat antara sesama variabel bebas, dimana semua angka VIF berada dibawah 5, hal ini menunjukan tidak terjadi multikolinearitas.

\subsection{Uji Heterokedastisitas}

Pengujian heteroskedastisitas bertujuan untuk melihat apakah dalam sebuah model regresi terjadi ketidaksamaan varians dari 
residual yang merupakan suatu pengamatan ke pengamatan yang lainnya. Model regresi yang baik adalah model yang bernilai tetap atau homoskedastisitas atau tidak terjadi heteroskedastisitas.

Deteksi heteroskedastisitas dilakukan dengan cara melihat ada tidaknya pola tertentu pada data yang diolah. Menurut Santoso (2004:208), dasar pengambilan keputusannya adalah:

a. Jika pola tertentu seperti titik-titik yang ada membentuk suatu pola tertentu yang teratur, maka terdapat situasi heteroskedastisitas.

b. Jika tidak ada pola yang jelas, serta titik-titik menyebar diatas dan dibawah angka nol pada sumbu Y, maka tidak terjadi heteroskedastisitas.

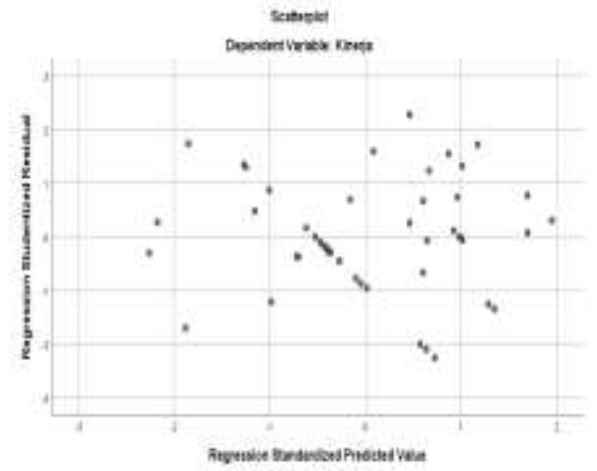

Gambar 2 Hasil Uji Heterokedastisitas
Pola Scatterplot seperti pada gambar diatas, terlihat titk-titik menyebar secara acak, tidak membentuk sebuah pola tertentu yang jelas, serta tersebar baik diatas maupun dibawah angka nol pada sumbu Y. Hal ini berarti tidak terjadi heteroskedastisitas pada model regresi, sehingga model regresi layak dipakai.

\section{Evakuasi dan Pembahasan \\ 3.1. Regresi Linear Berganda}

Teknik analisis data yang digunakan adalah regresi linier berganda (multiple linier regression method), untuk mempermudah dalam evaluasi data ini, maka penulis mencari nilai-nilai yang dibutuhkan dengan menggunakan perangkat lunak komputer yaitu program SPSS dengan hasil data seperti pada tabel diatas maka diperoleh pada table dibawah ini.

Tabel 2. Hasil Uji Regresi Linear Berganda

Coefficients $^{\mathrm{a}}$

\begin{tabular}{|c|c|c|c|c|c|c|c|c|}
\hline \multirow{2}{*}{\multicolumn{2}{|c|}{ Model }} & \multicolumn{2}{|c|}{$\begin{array}{c}\text { Unstandardized } \\
\text { Coefficients }\end{array}$} & \multirow{2}{*}{$\begin{array}{c}\text { Standardized } \\
\text { Coefficients } \\
\text { Beta }\end{array}$} & \multirow{2}{*}{$\mathrm{t}$} & \multirow{2}{*}{ Sig. } & \multicolumn{2}{|c|}{$\begin{array}{l}\text { Collinearity } \\
\text { Statistics }\end{array}$} \\
\hline & & B & $\begin{array}{l}\text { Std. } \\
\text { Error }\end{array}$ & & & & Tolerance & VIF \\
\hline \multirow{4}{*}{1} & (Constant) & 3.381 & 2.533 & & 1.335 & .188 & & \\
\hline & Gaya.Kep.Partisipatif & -.027 & .067 & -.032 & -.399 & .692 & .784 & 1.275 \\
\hline & Disiplin.Kerja & .189 & .088 & .178 & 2.149 & .037 & .712 & 1.404 \\
\hline & Lingkungan.Kerja & .728 & .080 & .783 & 9.110 & .000 & .664 & 1.506 \\
\hline
\end{tabular}

a. Dependent Variable: Kinerja

Hasil dari persamaan diatas :

$Y=3,381-0,027 X_{1}+0,189 X_{2}+0,728 X_{3}+$

Persamaan diatas dijelaskan bahwa koefesien $\mathrm{X}_{1}$ (gaya kepemimpinan partisipatif) mempunyai nilai negatif yaitu 0,027 , hal ini menunjukan bahwa variabel gaya kepemimpinan partisipatif mempunyai pengaruh negatif terhadap kinerja pegawai dan guru. Sementara itu pada persamaan diatas bahwa koefesien $\mathrm{X}_{2}$ (disiplin kerja) memiliki nilai positif yaitu 0,189 . Hal ini menunjukan bahwa variabel disiplin kerja mempunyai pengaruh positif terhadap kinerja pegawai dan guru. Sedangkan berdasarkan persamaan diatas bahwa koefesien $\mathrm{X}_{3}$ (lingkungan kerja) memiliki nilai positif yaitu 0,728 . Hal ini menunjukan bahwa variabel lingkungan kerja mempunyai pengaruh positif terhadap efektivitas kerja pegawai di SMA Negeri 1 NA IX-X Kabupaten Labuhanbatu Utara.

Hal ini berarti semua variabel gaya kepemimpinan partisipatif, disiplin kerja dan lingkungan kerja yang saat ini berlaku di SMA 
Negeri 1 NA IX-X Kabupaten Labuhanbatu Utara telah mampu meningkatkan kinerja pegawai dan guru walaupun nilainya tersebut bervariasi.

\subsection{Pengujian Simultan}

Hasil pengujian hipotesis berpengaruh secara simultan antara gaya kepemimpinan partisipatif, disiplin kerja dan lingkungan kerja terhadap kinerja pegawai dan guru dapat dilihat Tabel 3. Uji F pada tabel dibawah ini.

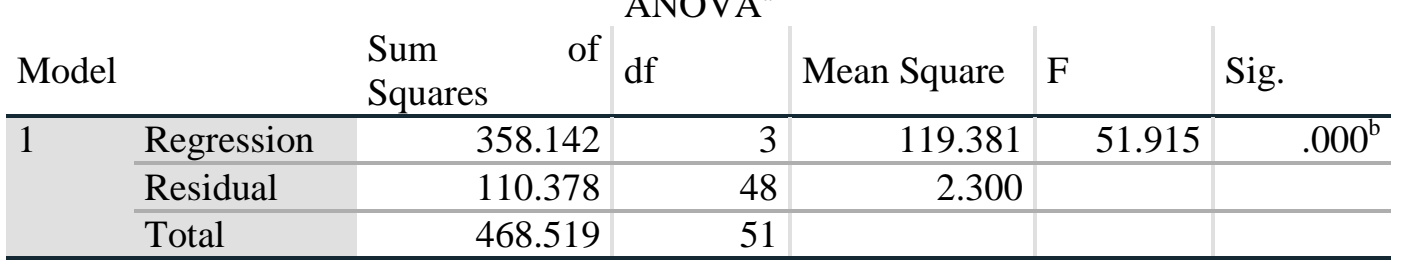

a. Dependent Variable: Kinerja

b. Predictors: (Constant), Lingkungan.Kerja, Gaya.Kep.Partisipatif, Disiplin.Kerja

Pada tabel diatas terlihat bahwa nilai Fhitung adalah 51,915 dan nilai signifikansi 0,000 . Dengan derajat bebasnya yaitu $\mathrm{df}_{1}=\mathrm{k}-$ $1=4-1=3$ dan $\mathrm{df}_{2}=\mathrm{N}-\mathrm{k}=52-4=48$, maka nilai F-tabel dengan tingkat kepercayaan $95 \%(\alpha: 0,05)$ adalah $\mathbf{2 , 8 0}$.

Oleh karena itu nilai F-hitung > F-tabel $(51,915>2,80)$ dan dengan nilai signifikansi $0,000<0,05$ maka Ha diterima dan Ho ditolak berarti hipotesis dalam penelitian ini yaitu bahwa gaya kepemimpinan partisipatif, disiplin kerja dan lingkungan kerja secara simultan berpengaruh signifikan terhadap kinerja pegawai dan guru di SMA Negeri 1 NA IX-X Kabupaten Labuhanbatu Utara.

\subsection{Pengujian Parsial}

Berdasarkan dari tabel coefficients pada uji multikolinearitas, maka diperleh data sebagai berikut. Terlebih dahulu kita menghitung t-tabel yang akan menjadi tolok ukur pada pengujian parsial pada tiap-tiap variabel $\mathrm{x}$ terhadap variabel y.

Dengan derajat bebas pengujian (df) adalah $\mathrm{N}-\mathrm{k}=52-4=48$. Maka nilai t-tabel pada tingkat kepercayaan $95 \%(\alpha: 0,05)$ adalah 2,010 .

\subsubsection{Pengaruh Gaya Kepemimpinan Partisipatif Terhadap Kinerja}

Dari tabel coefficients pada uji multikolinearitas, diperoleh hasil sebagai berikut:

Tabel 4. Hasil Uji Parsial $\mathrm{X}_{1}$ Terhadap Y Coefficients $^{\mathrm{a}}$

\begin{tabular}{|c|c|c|c|c|c|c|c|}
\hline \multirow[t]{2}{*}{ Model } & \multicolumn{2}{|c|}{$\begin{array}{l}\text { Unstandardized } \\
\text { Coefficients }\end{array}$} & \multirow{2}{*}{$\begin{array}{l}\text { Standardized } \\
\text { Coefficients } \\
\text { Beta } \\
\end{array}$} & \multirow[t]{2}{*}{$\mathrm{t}$} & \multirow[t]{2}{*}{ Sig. } & \multicolumn{2}{|c|}{$\begin{array}{l}\text { Collinearity } \\
\text { Statistics }\end{array}$} \\
\hline & $\mathrm{B}$ & Std. Error & & & & Tolerance & VIF \\
\hline Gaya.Kep.Partisipatif & -.027 & .067 & -.032 & -.399 & .692 & .784 & 1.275 \\
\hline
\end{tabular}

Berdasarkan tabel diatass diperoleh nilai thitung sebesar 0,889 , maka nilai t-hitung $<\mathrm{t}$ tabel $(-0,339<2,010)$, maka dapat disimpulkan Ho diterima dan Ha ditolak, yang artinya variabel gaya kepemimpinan partisipatif secara parsial tidak ada pengaruh signifikan kinerja pegawai dan guru di SMA Negeri 1 NA IX-X Kabupaten Labuhanbatu Utara.

\begin{tabular}{|c|c|c|c|c|c|c|c|}
\hline \multirow{3}{*}{ Model } & \multicolumn{4}{|c|}{$\begin{array}{c}\text { Tabel 5. Hasil Uji Parsial X } X_{2} \text { Terhadap Y } \\
\text { Coefficients }^{\mathrm{a}}\end{array}$} & \multirow{3}{*}{ Sig. } & \multirow{2}{*}{\multicolumn{2}{|c|}{$\begin{array}{l}\text { Collinearity } \\
\text { Statistics }\end{array}$}} \\
\hline & \multicolumn{2}{|c|}{$\begin{array}{l}\text { Unstandardized } \\
\text { Coefficients }\end{array}$} & \multirow{2}{*}{$\begin{array}{l}\text { Standardized } \\
\text { Coefficients } \\
\text { Beta }\end{array}$} & \multirow{2}{*}{$\mathrm{t}$} & & & \\
\hline & B & Std. Error & & & & Tolerance & VIF \\
\hline Disiplin.Kerja & .189 & .088 & .178 & 2.149 & .037 & .712 & 1.404 \\
\hline
\end{tabular}

\subsubsection{Pengaruh Disiplin Kerja Terhadap \\ Dari tabel coefficients pada uji multikolinearitas, diperoleh hasil sebagai berikut:}


Berdasarkan tabel diatass diperoleh nilai thitung sebesar 2,149, maka nilai t-hitung $>\mathrm{t}$ tabel $(2,149>2,010)$, maka dapat disimpulkan Ha diterima dan Ho ditolak, yang artinya variabel disiplin kerja secara parsial ada pengaruh signifikan kinerja pegawai dan guru

\subsubsection{Pengaruh Lingkungan Kerja Terhadap Kinerja}

Dari tabel coefficients pada uji multikolinearitas, diperoleh hasil sebagai berikut: di SMA Negeri 1 NA IX-X Kabupaten Labuhanbatu Utara.

\begin{tabular}{|c|c|c|c|c|c|c|c|}
\hline \multirow{3}{*}{ Model } & \multicolumn{5}{|c|}{$\begin{array}{c}\text { Tabel 6. Hasil UJi Parsial } \mathrm{X}_{3} \text { Terhadap Y } \\
\text { Coefficients }^{\mathrm{a}}\end{array}$} & \\
\hline & $\begin{array}{l}\text { Unst } \\
\text { Coef }\end{array}$ & $\begin{array}{l}\text { dized } \\
\text { ts }\end{array}$ & $\begin{array}{l}\text { Standardized } \\
\text { Coefficients }\end{array}$ & t & $\mathrm{Sio}$ & $\begin{array}{l}\text { Collinearit } \\
\text { Statistics }\end{array}$ & \\
\hline & B & Std. Error & Beta & & & Tolerance & VIF \\
\hline Lingkungan.Kerja & .728 & .080 & .783 & 9.110 & .000 & .664 & 1.506 \\
\hline
\end{tabular}

a. Dependent Variable: Kinerja

Berdasarkan tabel diatass diperoleh nilai thitung sebesar 9,110, maka nilai t-hitung > ttabel $(9,110>2,010)$, maka dapat disimpulkan Ha diterima dan Ho ditolak, yang artinya variabel lingkungan kerja secara parsial ada pengaruh signifikan kinerja pegawai dan guru di SMA Negeri 1 NA IX-X Kabupaten Labuhanbatu Utara.

\subsection{Pengujian Koefisien Determinasi}

Uji determinan adalah untuk mengetahui seberapa besar pengaruh variabel independen terhadap variabel dependen. Untuk melihat hasil uji determinan maka dapat diketahui nilai $\mathrm{R}$ Square atau koefesien determinasi dan dapat dilihat dibawah ini. Untuk variabel independen lebih dari dua sebaiknya menggunakan nilai Adjusted $\mathrm{R}^{2}$.

Tabel 7. Tabel Model Summary

Model Summary ${ }^{\mathrm{b}}$

\begin{tabular}{ll|l|l|l} 
Model & $\mathrm{R}$ & R Square & Adjusted R Square & $\begin{array}{l}\text { Std. Error of the } \\
\text { Estimate }\end{array}$ \\
\hline 1 & $.874^{\mathrm{a}}$ & .764 & .750 & 1.516 \\
\hline
\end{tabular}

a. Predictors: (Constant), Lingkungan.Kerja, Gaya.Kep.Partisipatif, Disiplin.Kerja

b. Dependent Variable: Kinerja

Maka pada tabel diatas menunjukan nilai Adjusted $\mathrm{R}^{2}$ adalah $75,0 \%$ variabel kinerja pegawai dan guru di SMA Negeri 1 NA IX-X Kabupaten Labuhanbatu Utara dapat dijelaskan oleh variabel gaya kepemimpinan partisipatif, disiplin kerja dan lingkungan kerja sedangkan sisanya tidak dilakukan dalam penelitian ini.

\section{Kesimpulan}

Berdasarkan pada analisis dan evaluasi data di atas, maka dapat ditarik kesimpulan dari penelitian ini sebagai berikut:

1) Variabel gaya kepemimpinan partisipatif secara parsial tidak berpengaruh postif dan tidak signifikan terhadap kinerja pegawai dan guru di SMA Negeri 1 NA IX-X Kabupaten Labuhanbatu Utara.

2) Variabel disiplin kerja secara parsial berpengaruh postif dan signifikan terhadap kinerja pegawai dan guru di SMA Negeri 1 NA IX-X Kabupaten Labuhanbatu Utara.
3) Variabel lingkungan kerja secara parsial berpengaruh postif dan signifikan terhadap kinerja pegawai dan guru di SMA Negeri 1 NA IX-X Kabupaten Labuhanbatu Utara.

4) Variabel gaya kepemimpinan partisipatif, disiplin kerja dan lingkungan kerja secara simultan berpengaruh positif dan signifikan terhadap kinerja pegawai dan guru di SMA Negeri 1 NA IX-X Kabupaten Labuhanbatu Utara.

\section{DAFTAR PUSTAKA}

Adrijanti, S. (2014). Pengaruh Kepemimpinan Kepala Sekolah, Motivasi Kerja Dan Disiplin Kerja Terhadap Kinerja Guru Di SDN Sumari Duduk Sampeyan Gresik. Jurnal Ilmiah Keguruan dan Ilmu Pendidikan.

Arianto, D. A. (2013). Pengaruh Kedisiplinan, Lingkungan Kerja dan Budaya Kerja 
Terhadap Kinerja Tenaga Pengajar. Jurnal Economia.

Arikunto, S. (2006). Metode Penelitian Kualitatif. Jakarta: Bumi Aksara.

Asmiarsih, T. (2006). Pengaruh Pengawasan Terhadap Disiplin Kerja Pegawai Badan Kepegawaian Daerah Kabupaten Brebes. Semarang: Fakultas Ilmu Sosial, Universitas Negeri Semarang.

Budianto, A. T., \& Kartini, A. (2015). Pengaruh Lingkungan Kerja. Terhadap Kinerja Pegawai Pada PT Perusahaan Gas Negara (Persero) Tbk SBU Distributor Wilayah I Jakarta. Jurnal Ilmiah Manajemen Universitas Pamulang.

Danim, S. (2002). Menjadi Peneliti Kualitatif. Bandung: Pustaka Setia.

Darmawan, R. B. (2019). Pengaruh Lingkungan Kerja, Stres Kerja dan Motivasi terhadap Kinerja Karyawan pada PT. BPRS Sukowati Sragen.

Daryanto. (2001). Evaluasi Pendidikan. Jakarta: Rineka Cipta.

Fajrie, M. (2015). Pengaruh Gaya Kepemimpinan Partisipatif, Komunikasi Interpersonal, Dan Sistem Penghargaan Terhadap Kinerja Guru Sekolah Dasar Negeri Di Kota Depok. Depok.

Fathoni, A. (2006). Manajemen Sumber Daya Manusia. Bandung: Rineka Cipta.

Hamalik, O. (2010). Proses Belajar Mengajar. Jakarta: PT. Bumi Aksara.

Handoko, H. T. (2001). Manajemen Personalia Dan Sumber Daya Manusia,Edisi Kedua. Yogyakarta: BPFE.

Hasibuan, M. S. (2002). Manajemen Sumber Daya Manusia. Jakarta: PT. Bumi Aksara.

Hasibuan, M. S. (2007). Manajemen Sumber Daya Manusia. Cetakan 9. Jakarta: PT. Bumi Aksara.

Hasibuan, M. S. (2013). Manajemen Sumber Daya Manusia. Jakarta: PT. Bumi Aksara.

Heidjrachman, \& Husnan. (2002). Manajemen Personalia. Yogyakarta: BEFE.

Hersey, \& Blanchard. (2004). Management of Organizational Behavior : Utilizing Human Resource. New Jersey: Prentice Hall.

Iskandar, R. Z. (2018). Pengaruh Motivasi dan Lingkungan Kerja Terhadap Kinerja Guru. Jakarta: Universitas Islam Negeri Syarif Hidayatullah.

Kartono, K. (2008). Pemimpin dan Kepemimpinan. Jakarta: PT. Raja. Grafindo Persada.
Kusmianto. (1997). Panduan Penilaian Kinerja Guru Oleh Pengawas. Jakarta: Erlangga.

Lewa, Eka, \& Subowo. (2005). Pengaruh Kepemimpinan, Lingkungan Kerja Fisik dan Kompensasi Terhadap Kinerja Karyawan di PT. Pertamina (Persero) Daerah Operasi Hulu Jawa Bagian Barat, Cirebon. Jurnal Sinergi.

Lubis, A. F., \& Syahputra, A. (2008). Pedoman Penulisan Proposal dan Tesis. Medan: Program Magister Akuntansi Sekolah Pascasarjana USU.

Lubis, S. K. (2000). Hukum Ekonomi Islam. Jakarta: Sinar Grafika.

Mangkunegara, A. P. (2006). Perencanaan Dan Pengembangan Manajemen Sumber Daya Manusia. Bandung: PT Refika Aditama.

McCrimmon, M. (2007). The Ideal Leader. Ivey Business Journal.

Mulyasa, A. (2003). Kurikulum Berbasis Kompetensi. Bandung: Remaja Rosda.

Mulyasa, A. (2007). Standar Kompetensi Dan Sertifikasi Guru. Bandung: Remaja.

Munandar, S. U. (1992). Mengembangkan Bakat Dan Kreativitas Anak Sekolah. Jakarta: Gramedia.

Nawawi, H. (2005). Penelitian Terapan. Yogyakarta: Gajah Mada University. Press.

Nawawi, H. (2012). Metode Penelitian Bidang Sosial. Yogyakarta: Gajah Mada University Press.

Nuryasin, I., Al Musadieq, M., \& Ruhana, I. (2016). Pengaruh Lingkungan Kerja Dan Motivasi Kerja Terhadap Kinerja Karyawan (Studi Pada Karyawan Perusahaan Daerah Air Minum (PDAM) Kota Malang). Jurnal Universitas Brawijaya.

Pidarta, M. (1999). Manajemen Pendidikan. Jakarta: PT. Bina Aksara.

Priansa , D. J. (2014). Perencanaan \& Pengembangan SDM. Bandung: Alfabeta.

Rahmawati, F. (2014). Pengaruh Lingkungan kerja, Keterampilan Kerja dan Jenjang Karir Terhadap Kinerja Karyawan.

Riyono, B., \& Zulaifah, E. (2001). Pengaruh Kompensasi Finansial, Gaya Kepemimpinan, dan Motivasi Kerja Terhadap Kinerja Karyawan pada Perusahaan Manufaktur di Jawa Timur. Jurnal Manajemen dan Kewirausahaan, Vol. 13 No. 1, 40-45.

Robbins, S. P. (1996). Perilaku Organisasi Edisi ke 7 (Jilid II). Jakarta: Prehallindo.

Robbins, S. P., \& Judge. (2002). Perilaku Organisasi, Buku Kedua. Jakarta: Salemba. 
Sagala, S. (2013). Konsep dan Makna Pembelajaran. Bandung: Alfabeta.

Saksono, S. (1998). Administrasi Kepegawaian. Yogyakarta: Kanisius.

Samsudin, S. (2006). Manajemen Sumber Daya Manusia. Cetakan ke-1. Bandung: Pustaka.

Sastrohadiwiryo, B. S. (2003). Manajemen Tenaga Kerja Indonesia Pendekatan Administrasi dan Operasional. Jakarta: Bumi Aksara.

Saydam, G. (2005). Manajemen Sumber Daya Manusia : Suatu Pendekatan Mikro. Jakarta: Djambaran.

Simanjuntak, P. J. (2005). Manajemen dan Evaluasi Kinerja. Jakarta: Fakultas Ekonomi Universitas Indonesia.

Siswanto. (2002). Manajemen Tenaga Kerja Indonesia. Jakarta: Bumi Aksara.

Soejono. (2000). Manajemen Sumber Daya Manusia. Bandung.

Soenarno, A. (2003). Kamus Istilah Pariwisata dan Perhotelan. Bandung: Angkasa.

Sugiyono. (2011). Metode Penelitian Kuantitatif, Kualitatif dan R\&D. Bandung: Alfabeta.

Sugiyono. (2014). Metode Penelitian Pendidikan Pendekatan Kuantitatif, Kualitatif, dan R\&D. Bandung: Alfabeta.

Suharsaputra, U. (2010). Administrasi Pendidikan. Bandung: Refika Aditama.

Sulistyorini. (2001). Hubungan Antara Keterampilan Manajerial Kepala Sekolah Dan Iklim Organisasi Dengan Kinerja Guru. Jurnal Ilmu Pendidikan.
Supardi. (2014). Kinerja Guru. Jakarta: PT. Raja Grafindo Persada.

Sutrisno, E. (2009). Manajemen Sumber Daya Manusia. Edisi Pertama. Jakarta: Kencana Prenada Media Group.

Tentang Guru Dan Dosen, Undang-Undang Republik Indonesia Nomor 14 Tahun 2005.

Tentang Sistem Pendidikan Nasional, UndangUndang Republik Indonesia Nomor 20 Tahun 2003.

Tentang Standar Proses Pembelajaran, Permendiknas Ri No. 41 Tahun 2007.

Tentang Standar Proses Untuk Satuan Pendidikan, Menteri Pendidikan Nasional Republik Indonesia Nomor 41 Tahun 2007.

Thoha, M. (2001). Dinamika Usaha Kecil Dan Rumah Tangga. Jakarta: PEP-LIPI.

Thoha, M. (2010). Kepemimpinan Dalam Manajemen. Jakarta: PT. Raja. Grafindo Persada.

Tjiptono, F. (2001). Manajemen Jasa. Yogyakarta: Penerbit Andi.

Triton. (2006). SPSS 12.00 Terapan Riset Statistik Parametrik. Yogyakarta: Andi.

Veithzal, R. (2005). Manajemen Sumber Daya Manusia. Jakarta: Raja Grafindo.

Veithzal, R. (2011). Manajemen Sumber Daya Manusia Untuk Perusahaan dari Teori dan Praktik. Jakarta: PT. Raja Grafindo Persada.

Yukl, A. G. (1998). Kepemimpinan Dalam Organisasi, Edisi Bahasa Indonesia: Yusuf Udaaya. Jakarta: Prenhallindo. 